\title{
UPAYA MENINGKATKAN KEMAMPUAN SERVIS ATAS MELALUI PENERAPAN LATIHAN MENGGUNAKAN DUMBBELL PADA SISWA KELAS X IPS 6 SMA PLUS NEGERI 7 BENGKULU
}

\author{
Tri susanto \\ PENJAS FKIP UNIB, e-mail: susantotri2795@gmail.com \\ Tono Sugihartono \\ Universitas Bengkulu \\ Dian Pujianto \\ Universitas Bengkulu
}

\begin{abstract}
Abstrak
Penelitian ini bertujuan untuk meningkatkan kemampuan servis atas dengan penerapan dumbbell pada permainan bola voli siswa kelas X IPS 6 SMA Plus Negeri 7 Bengkulu. Metode penelitian tindakan kelas dengan rancangan terdiri atas prasiklus. siklus I, dan siklus II, di mana siklus I dan siklus II dilakukan empat tahap pelaksanaan yaitu. 1) perencanaan, 2) aksi atau tindakan, 3) obserpasi, dan 4) refleksi. Subjek penelitian ini adalah adalah siswa kelas X IPS 6 SMA Plus Negeri 7 Bengkulu sebanyak 30 orang, yang terbagi menjadi 6 perempuan dan 24 lakilaki., tempat penelitian dilaksanakan di SMA Plus Negeri 7 Bengkulu. Berdasarkan hasil penelitian meningkatkan kemampuan servis atas menggunakan dumbbell. Pada prasiklus hasil tes servis atas menggunakan dumbbell memperoleh hasil nilai rata-rata ketuntasan siswa sebesar $16,66 \%$. Pada siklus I hasil nilai rata-rata keterampilan tes kemampuan servis atas pada olahraga bola voli meningkat menjadi $50 \%$, sedangkan hasil nilai rata-rata keterampilan tes kemampuan servis atas aktivitas guru dengan nilai 7. Pada siklua II hasil nilai rata-rata keterampilan tes kemapuan servis atas menggunakan dumbbell memperoleh hasil rata-rata $76,66 \%$ sedangakan aktifitas guru siklus ke II menjadi 10 . Berdasarkan penelitian tersebut dapat disimpulkan bahwa latihan dumbbell meningkatkan kemampuan servis atas pada Siswa Kelas $\mathrm{X}$ Ips 6 SMA Plus Negeri 7 Bengkulu.
\end{abstract}

Kata Kunci: Service Atas, Dumbbell dan Permainan Bola Voli

\section{Abstract}

This study aims to improve the top service capability by applying dumbbell on the students' volleyball game of class X IPS 6 SMA Plus Negeri 7 Bengkulu. The classroom action research method with the design consists of prasiklus. Cycle I, and cycle II, where cycle I and cycle II are done four stages of implementation that is. 1) planning, 2) action or action, 3) obserpation, and 4) reflection. The subjects of this research are students of class X IPS 6 SMA Plus Negeri 7 Bengkulu as many as 30 people, divided into 6 women and 24 men, where the research 
conducted in SMA Plus Negeri 7 Bengkulu. Based on the results of the study improve the serviceability of using dumbbell load. In prasiklus the results of top service tests using dumbbell load obtained the results of the average score of students mastery of $16.66 \%$. In the first cycle, the average score of the skills of the top serviceability test in volleyball increased to $50 \%$, while the average score of the skill of service ability test on teacher activity was 7 . On the second score the average score of skill test Top service using dumbbell obtained an average yield of $76.66 \%$ while the activity of teachers to cycle II to 10 . Based on the research it can be concluded that the dumbbell load training improves the service capability on the students of Class X Ips 6 Sma Plus Negeri 7 Bengkulu.

\section{Keywords: Top Service, Dumbbell and Game volleyball}

\section{PENDAHULUAN}

Olahraga merupakan bagian dari aktivitas sehari-hari manusia yang berguna untuk membentuk jasmani dan rohani yang sehat. Sampai saat ini olahraga memberikan kontribusi yang positif dan nyata bagi peningkatan kesehatan masyarakat. Olahraga di Indonesia tidak hanya berperan untuk kepentingan pendidikan, rekreasi dan kesegaran jasmani, tetapi juga sebagai ajang pembentukan prestasi

Permainan bola voli merupakan permainan yang komplek dan digemari diseluruh lapisan masyarakat, ini terbukti dengan banyaknya lapangan dan masyarakat yang bermain bola voli disetiap daerah sampai ke pelosok desa. Bermain bola voli tidaklah gampang apalagi bila berbicara tentang servis, terutama pada saat servis atas banyak hal yang harus diperhatikan.

Sekolah adalah lembaga pendidikan formal yang berperan sebagai wadah mendidik siswa untuk cerdas, terampil, dan memiliki wawasan yang luas dan juga dapat berfungsi untuk mencari bibit unggul dalam bidang olahraga. Mencari bibit unggulan tidaklah mudah maka harus ada suatu kerjasama antara lembaga masyarakat dan berbagai pihak terkait. Seorang siswa yang memiliki bakat dan kemampuan dalam bidang olahraga tertentu mesti dibina secara baik dan aktif agar siap berprestasi. Khususnya prestasi olahraga bola voli yang sangat membutuhkan perhatian dari pemerintah.

Menurut Ahmadi (2007:64) bola voli adalah salah satu jenis olahraga yang banyak mengandalkan fisik, maka kondisi fisik pemain sangat penting dalam menunjang efektivitas permainan. Diperlukan penerapan yang tepat untuk mningkatkan kemampuan fisik pemain, seperti kecepatan, kelicahan gerakan, kekuatan pukulan, ketinggian loncatan, dan sebagainya. Termasuk salah satunya adalah teknik servis atas dan penempatan yang baik dalam bermain. Berdasarkan uraian diatas, maka salah satu penerapan untuk mengembangkan kemampuan dalam penempatan servis atas adalah dengan latihan servis atas menggunakan dumbbell. Ada berbagai macam bentuk latihan yang dapat meningkatkan kemampuan servis atas, maka bentuk latihan servis atas menggunakan beban tangan dumbbell. Merupakan salah satu bentuk latihan yang bertujuan untuk meningkatkan kemampuan servis atas yang berhubungan dengan penempatan servis atas pemain pada saat bermain bola voli.

Sekolah merupakan lembaga pendidikan formal yang berperan sebagai wadah mendidik siswa untuk cerdas, terampil, dan 
memiliki wawasan yang luas juga dapat berfungsi untuk mencari bibit unggul dalam bidang olahraga. Mencari bibit unggulan tidaklah mudah harus ada suatu kerjasama antara lembaga masyarakat dan berbagai pihak terkait. Seorang siswa yang memiliki bakat dalam bidang olahraga tertentu harus dibina secara baik dan aktif supaya siap berprestasi. Permasalahan yang sering dihadapi sekolah dalam membina siswa dibidang olahraga adalah kurangnya motivasi siswa dalam belajar suatu cabang olahraga tertentu khususnya bola voli. Siswa cenderung menganggap olahraga ini hanya sebagai hiburan semata. Mereka kurang serius dalam memfokuskan diri ke cabang olahraga yang mereka gemari ini padahal mereka memiliki minat dan bakat dalam olahraga bola voli. Khususnya di SMA Plus Negeri 7 Bengkulu, prestasi olahraga bola voli sangat kurang dalam beberapa tahun terakhir, ini sejalan dengan yang dikatakan pelatih sekaligus guru olahraga Hardiansyah, bahwa tingkat prestasi permainan bola voli cendrung menurun dan sering saat bertanding para siswa saat servis tidak sampai, keluar dan tersangkut pada net ini dikarenakan kurang dalam hal penempatan servis atas pada permainan bola voli, karena lemahnya teknik dasar yang mereka miliki pada saat melakukan servis atas itu mengakibatkan pukulan servis atas mereka tidak akurat.

Berdasarkan Pengamatan terhadap proses pembelajaran permainan bola voli di SMA Plus Negeri 7 Bengkulu menunjukkan banyak ditemukan masalah dalam melakukan servis atas bola voli, diantaranya mereka masih belum mengetahui penempatannya atau ketepatan pada saat melakukan servis. Maka dari itu, dengan memberikan latihan dumbbell kepada para siswa dapat memberikan perubahan kepada mereka dalam melakukan ketepatan servis atas yang benar,terarah dan mematikan passing lawansehingga tim bisa mendapatkan poin dalam permainan bola voli.

Sehubungan dengan masalah itu, siswa perlu diajarkan bagaimana mempunyai kekuaatan lengan saat melakukan servis atas karena rata-rata dari 30 siswa pada obsevasi awal 50\% siswa kuang efektif dalam melakukan sevice atas sehingga latihan dengan menggunakan dumbbell pelu dilakukan tujuannya untuk meningkatkan kekuatan lengan dan melatih ketepatan dalam melakukan servis atas bola voli. Sesuai dengan perkembangannya ada beberapa macam servis atas dalam permainan bola voli, namun yang perlu dipelajari adalah ketepatan dalam melakukan servis atas, tujuannya adalah untuk mematikan bola ke daerah lawan dan mendapatkan poin dari lawan karena lawan sulit mengontrol passing pada servis atas terarah tersebut, sehingga memenangkan suatu pertandingan. Berdasarkan dari hal itu maka penulis tertarik untuk mengadakan penelitian di SMA Plus Negeri 7 Bengkulu tentang "Meningkatkan Kemampuan Servis Atas Dengan Penerapan Latihan Menggunakan Dumbbell. Permasalahn yang ditemukan yaitu 1 . Kurangnya motivasi siswa dalam belajar suatu cabang olahraga 2 . Kurang serius dalam memfokuskan diri ke cabang olahraga 3. Banyak kekurangan dalam hal penempatan servis atas, 4. Lemahnya teknik dasar yang mereka miliki 5. masih belum mengetahui penempatannya pada saat melakukan servis atas. Dari permasalahan tersebut maka peneliti membatasi penelitian ini dengan Upaya meningkatkan kemampuan servis atas melalui penerapan latihan 
dumbbell dalam bermain bola voli siswa kelas XIPS 6 SMA Plus Negeri 7 Bengkulu". Sedangkan untuk rumusan masalah yang di ajukan pada penelitian ini adalah Apakah dengan penerapan latihan dumbbell dapat meningkatkan kemampuan servis atas dalam permainan bola voli siswa kelas X IPS 6 SMA Plus Negeri 7 Bengkulu?. tujuan penelitian ini adalah untuk meningkatkan kemampuan servis atas dengan penerapan dumbbell pada permainan bola voli siswa kelas X IPS 6 SMA Plus Negeri 7 Bengkulu. Manfaat penelitian ini, 1. Bagi peneliti, mampu memberikan wawasan yang lebih luas dan bisa di terapkan di masyarakat. 2. Bagi para guru dan pembina olahraga bola voli sebagai bahan masukan dalam memberikan program latihan kondisi fisik atlet bola voli khususnya meningkatkan kemampuan servis atas dengan penerapan latihan servis atas menggunakan dumbbell. 3 . Bagi siswa penelitian ini dapat dijadikan sebagai acuan atau tolak ukur untuk meningkatkan servis atas dengan penerapan dumbbell

\section{METODE}

Jenis penelitian ini adalah Penelitian Tindakan Kelas (classroom action research). Menurut Suharsimi Arikunto dalam Endang Komara (2012:79) penelitian tindakan kelas adalah suatu pencermatan terhadap kegiatan yang sengaja di munculkan, dan terjadi dalam kelas dan lapangan. Penelitian tindakan kelas ini menggunakan metode deskriptif, data yang di dapatkan adalah data kuantitatif yang kemudian di interprestasikan secara kualitatif karena penelitian tindakan kelas ini bertujuan untuk mendeskripsikan dan menganalisis fenomena serta proses yang melibatkan siswa dengan melihat peningkatan kemampuan service atas melalui latihan dumbbell. Adapun tempat penelitian yaitu di SMA Plus Negeri 7 Bengkulu di kelas X IPS 6, waktu penelitian di laksanakan pada semester genap tahun ajaran 2016/2017. Subjek dalam penelitian ini Sebagai subjek pada penelitian ini adalah siswa kelas X IPS 6 SMA Plus Negeri 7 Bengkulu sebanyak 30 orang, yang terbagi menjadi 6 perempuan dan 24 laki-laki. Sesuai dengan maksud dan tujuan penelitian ini, Teknik pengumpulan data dilakukan dengan tes awal, setiap siswa melakukan servis atas ke sasaran yang sudah ditentukan dan dinilai setiap hasilnya. Tes ini dilakukan pada siswa sebelum melakukan latihan dumbbell. Kemudian siswa diberikan pembelajaran bola voli dan khususnya masalah service terutama service atas dengan menggunakan metode dumbbell untuk meningkatkan kemampuan servis atas siswa sesuai pelaksanaan tindakan kelas diatas, maka pada akhir pembelajaran dan latihan pada akhir siklus, peneliti mengambil data pada tahap-tahap analisis dan refleksi.

\section{HASIL DAN PEMBAHASAN Hasil}

Berdasarkan hasil penjelasan serta uraian yang telah dikumpulkan sebelumnya, maka pada bab ini akan mencari hasil penelitian analisis data dan pembahasan yang diperoleh dengan menggunakan perhitungan. Dari satu kelas yang dijadikan penelitian tentang servis. Semua siswa dalam satu kelas dijadikan sampel yaitu 30 siswa dan memenuhi persyaratan untuk diolah dalam penelitian ini.

Data lengkap mengenai hasil tes awal dan tes akhir kemampuan servis atas menggunakan dumbbell dapat dilihat pada lampiran. Deskripsi data dari masing-masing variabel dikemukakan Pada bagian ini setelah dilakukan rangkaian proses penelitian, selanjutnya peneliti akan menyajikan hasil penelitian antara lain; 1) Berkaitan dengan 
prosedur penelitian dan temuan dalam bentuk siklus-siklus penelitian, 2) Menyajikan deskripsi data-data hasil penelitian.

Tes awal

Hasil dari tes awal yang dilaksanakan pada prasiklus, menunjukkan bahwa masih banyak siswa Berdasarkan dari pengambilan data awal tersebut menunjukan bahwa siswa perlu mendapatkan pelajaran yang efektif dalam mencapai hasil belajar yang diinginkan. Hal-hal yang menyebabkan rendahnya tingkat keberhasilan tersebut diantaranya siswa tidak mengetahui cara melakukan servis atas yang baik, Untuk itu peneliti merasa perlu suatu tindakan perbaikan pembelajaran dengan menggunakan alat bantu beban sehingga upaya peningkatkan kemampuan servis atas dapat di lakukan dengan baik

Siklus I

dari hasil tes siklus 1 sebanyak 5 siswa mencapai kriteria baik $(16,66 \%), 10$ siswa dengan kriteria cukup (33,33\%) dan 12 siswa dengan kriteria kurang (40\%) dan 3 siswa dengan kriteria kurang sekali(10\%). Dari hasil data tersebut terlihat adanya peningkatan hasil belajar servis atas pada siswa tetapi belum seluruh siswa, setelah diamati peneliti bersama-sama guru PJOK dan teman sejawat, masih terdapat siswa yang belum melakukan servis atas dengan bernar.

Siklus II

dari hasil tes siklus II sebanyak 16 siswa mencapai kriteria baik (53,33\%), 7siswa dengan kriteria cukup (23,33\%), 7 siswa dengan kriteria kurang (23,33\%). Dari hasil data tersebut terlihat adanya peningkatan keberhasilan pembelajaran siswa melakukan servis atas menggunakan dumbbell dalam pembelajaran olahraga bola voli. Pada siklus II ini peningkatan keberhasilan dengan nilai ratarata secara klasikal sudah mencapai nilai tuntas yaitu nilai 76,66. Pada siklus 2 peneliti menganggap nilai keberhasilan siswa sudah mencapai yang diharapkan, jadi penelitian ini di akhiri pada siklus 2 .

\section{Pembahasan}

Berdasarkan prosedur penelitian tindakan kelas yang sudah dirancang dan dilaksanakan dengan sistematis, peneliti dapat mengumpulkan data penelitian yang mungkin dapat berupa informasi penting dari hasil penelitian. Penggunaan dumbbell dalam upaya meningkatkan kemampuan servis atas berdampak positif terhadap peningkatan hasil belajar siswa dalam melakukan servis atas dengan benar.

Hasil tes siklus satu mendapatkan peningkatan dari prasiklus dimana Hasilnya adalah sebagian besar siswa belum melakukan servis atas dengan benar, dari 30 siswa hanya 5 siswa (16,66\%) yang mampu melakukan servis atas dengan benar, dengan kriteria cukup, 14 siswa dengan kriteria kurang (46,66\%) dan 11 siswa dengan kriteria kurang sekali $(36,66 \%)$. Setelah dilakukan pengetesan awal maka dilakukan beberapa latihan. Latihan adalah proses pembiasaan yang dilakukan secara berulang-ulang sehingga terjadi adaptasi garak dan otomatis gerakan yang awalnya dirasakan sangat sukar akan menjadi sangat mudah setelah melakukan latihan yang diberikan secara sistematis dan teratur Ahmadi (2007:42).

Pada siklus I, peneliti bersama-sama guru PJOK, menyusun rencana pembelajaran untuk peningkatan keterampilan siswa. Pada penelitian ini digunakan dumbbell . Pada siklus I ini, terjadi peningkatan keberhasilan siswa melakukan servis atas, 5 siswa (16,66\%) mencapai kriteria nilai baik, jadi terdapat peningkatan dari tes awal yang siswa tidak ada dengan kategori baik. Untuk kategori cukup sebanyak 10 siswa (33,33\%), 12 siswa (40\%) 
masuk kategori kurang dan 3 siswa (10\%) dengan kriteria kurang sekali.

Walaupun terjadi peningkatan keberhasilan belajar siswa, akan tetapi hasil tersebut belum mencapai kriteria yang diharapkan, dikarenakan rata-rata nilai keseluruhan siswa belum mencapai KKM yaitu nilai 75. Hal ini menunjukkan masih terdapat kekurangan dalam pembelajaran servis atas dalam pembelajaran olahraga bola voli. Untuk itu penelitian dilanjutkan pada siklus II.

Siklus kedua dilakukan perbaikan pada program latihan dan Siswa yang berhasil melakukan servis atas dengan benar meningkat menjadi 16 siswa (53,33\%) dengan kriteria baik, 7 siswa (23,33\%) dengan kriteria cukup, dan 7siswa (23,33\%) dengan kriteria kurang. Dari hasil siklus II ini peneliti merasa sudah cukup meningkatkan keberhasilan belajar siswa, karena secara keseluruhan/klasikal nilai siswa telah mencapai KKM mata pelajaran PJOK sebesar nilai 76,66. Dengan ini peneliti merasa, penelitian tentang "upaya Meningkatkan Kemampuan Servis Atas Melalui Penerapan Latihan Menggunakan Dumbbell Pada Siswa Kelas X Ips 6 Sma Plus Negeri 7 Bengkulu sudah memnuhi keinginan dan syarat dlam penelitian. Dari hasil penelitian sejalan dengan yang dikemukakan oleh Haller David dalam Djubaera (2004:9) menyatakan bahwa salah satu latihan yang paling baik untuk memperkuat otot lengan dan dada adalah latihan dumbell dan push up. Latihan Dumbbell merupakan salah satu bentuk latihan kemampuan otot untuk mendesakkan tekanan terhadap suatu perlawanan (resistance) dan kekuatan bisa diatur oleh sekumpulan perlawanan otot yang dapat mengatasinya. Dimanan dalam penelitian ini latiahan dumbbell memberikan peningkatan kemampuan servis atas yang telah dibuktikan dalam penjelasan diatas.

\section{PENUTUP}

Simpulan

Setelah seluruh rangkaian kegiatan Penelitian Tindakan Kelas (PTK) di kelas Kelas $X$ IPS 6 Sma Plus Negeri 7 Bengkulu selesai dilaksanakan, maka dapat disimpulkan bahwa terjadi peningkatan hasil belajar servis atas, terlihat jelas dari hasil pra siklus, siklus I, dan siklus II. Berdasarkan hasil penelitian dan pembahasan dari hasil kegiatan pembelajaran yang dilakukan selama dua siklus, dan berdasarkan seluruh pembahasan serta analisis yang telah dilakukan dapat disimpulkan Dengan menggunakan dumbbell dapan meningkatkan kemampuan servis atas pada pembelajaran olahrag bola voli. Hasil tes awal hingga tes siklus II menunjukkan peningkatan, dimana pada tes awal tingkat ketuntasan belajar siswa secara keseluruhan sebesar 16,66\%. Pada tindakan siklus I meningkat menjadi $50 \%$ dan pada siklus II meningkat menjadi $76,66 \%$ dengan artian secara keseluruhan nilai siswa sudah mencapai KKM. Dengan menggunakan dumbbell selain juga dapat meningkatkan hasil belajar servis atas dalam pembelajaran oahraga bola voli, juga dapat memperbaiki proses pembelajaran. Dengan penggunaan alat bantu beban kemampuan siswa akan keberhasilan dalam belajar menjadi meningkat, karena mereka saat melakukan servis atas yang salah dengan kemampuan yang kurang maksimal maka siswa akan berusahaa meningkatkan kemampuan servis atas dengan menggunakan dumbbell supaya mereka dapan memiliki kemampuan servis atas yang baik dan benar.

\section{Saran}

Penggunaan dumbbell pada pembelajaran olahraga bola voli menurut hasil penelitian ini memberikan pengaruh dan dampak yang baik bagi hasil pembelajaran, 
baik dari segi keterampilan maupun proses pembelajaran. Maka dalam kesempatan ini peneliti memberikan saran sebagai berikut:

1. Disarankan kepada semua guru PJOK untuk mencoba menggunakan dumbbell dengan baik, sehingga hasil yang diharapkan juga lebih baik.

2. Guru dapat mengunakan dumbbell seperti pada penelitian ini sehingga dapat meningkatkan kemampuan .

3. servis atas dalam pembelajaran olahrag bola voli.

\section{DAFTAR PUSTAKA}

Ahmadi, Nuril. (2007). Panduan Olahraga Bola Voli. Surakarta : Era Pustaka Utama.

Arikunto, Suharsimi. (2010). Prosedur penelitian. Jakarta : Bumi Aksara

Edwan, Ari, dan Bogy. 2017. "Pengaruh Metode Latihan Plyometric Terhadap Kemampuan Jumping Smash Bola Voli Siswa Ekstrakurikuler SMPN 1 Bermani Ilir Kabupaten Kepahiang" Jurnal Kinestetik, Vol. 1 (1).

Endang, komara.(2012). Penelitian tindakan kelas. Bandung : Refika aditama

Gobel, Djubaera. (2004). Skripsi (Pengaruh Latihan Dumbell Terhadap Ketepatan Servis Bawah Pada Permainan Bola Voli). Jurusan Pendidikan Keolahragaan: IKIP Negeri Gorontalo.

Tangkudung James. (2012). Kepelatihan Olahraga Pembinaaan Prestasi Olahraga Jakata : Cerdas Jaya. ,(2016)Macam-Macam

Metodologi Penelitian. Jakarta : Lensa Medua Pustaka Indonesia.
(2018)Sport Psychometrics DasarDasar dan Instrument Psikometri, Depok: Raja grafindo persada. 
